11 Carson P, Oldroyd K, Phadke K. Myocardial infarction due to amphetamine. $\mathrm{Br}$ Med $\mathrm{J}$ 1987;294:1525.

12 Pentel PA, Wikell FR, Zavoral JH. Myocardial injury after phenylpropanolamine ingestion. Br Heart J 1982;47:51.

13 Horowitz ID, Lang WG, Kowes LG, et al. Hypertensive responses induced by PPA in anoretic and decongestant preparations. Lancet 1980;i:60-1.

14 McEwen J. PPA associated hypertension after the use of "over-the-counter" appetive suppressant product. Med J Aust 1983;2:71-3.

15 Frewin DB, Leonello PP, Frewin ME. Hypertension after ingestion of Trimolets. Med $J$ Aust 1978;2:497-8.

16 Adams HD, Butler MJ, Biller J, Toffol GJ. Nonhemorraghic cerebral infarction in young adults. Arch Neurol 1986;43:793-6.

17 Magargal LE, Sandborn GE, Donoso LA, Gonder JR. Branch retinal artery occlusion after excessive use of nasal spray. Ann Ophthalmol 1985; 17:500-1.

18 Karch FE, Lasagna L. Toward the operational identification of adverse drugs reactions. Clin Pharmacol Ther 1977;21:247-54.

\section{Calcitonin for pseudoclaudication in lumbar} spinal stenosis

Sir: "Pseudoclaudication" or intermittent claudication of the cauda equina is closely related to lumbar spinal stenosis (LSS), for which the only known effective treatment is surgical decompression by wide laminectomy (averaging three vertebrae), with an optimum success rate of 66 to $85 \%$. $^{2}$

The pathogenesis is still controversial; however, many consider vascular insufficiency of the nerve roots as a main causative mechanism. ${ }^{13}$ The observed beneficial effects on pseudoclaudication in patients with Paget's disease of bone, who have been treated with calcitonin, ${ }^{4}$ raises the possibility that this hormone may be useful in pseudoclaudication in non-Paget's patients, owing to its effectiveness in lowering the metabolic activity of the bone and, consequently, its blood supply. ${ }^{56}$ Such a mechanism may permit more blood to reach neural tissues.

A single clinical trial using calcitonin for the treatment of pseudoclaudication in nonPaget's LSS patients showed promising results. $^{3}$

Based on these data, we administered calcitonin to six patients suffering from neural pseudoclaudication. The diagnosis of LSS was considered when the patient had a combination of pseudoclaudication, unlimited "bicycling" ability while supine, no signs of peripheral vascular disease, and the demonstration of lumbar spinal canal stenosis on spinal CT scan and/or myelography. The aetiology of LSS was either osteoarthritic-spondylotic or combined with discopathy.

All patients were manual workers. Their mean age was 63 years and their chief complaint was intermittent claudication when walking. Duration of symptoms was 4-8 months in three patients and 3-10 years in the others.

Other complaints were low back pain, paraesthesia in one or both legs, muscle cramps, standing discomfort, and in two patients, episodes of urinary incontinence.

A variety of analgesics and different modes of physical therapy were tried and considered not helpful.

Neurological examination revealed decreased or absent ankle reflexes in five patients, decreased or absent patellar reflexes in two patients, weakness of one leg in three patients and positive straight leg raising in one.

Clinical and electromyographic evidence of peripheral neuropathy was present in four patients. Impaired glucose tolerance test was found in two patients and decreased serum vitamin B-12 in one.

Each patient was treated with intramuscular injections of Salmon calcitonin
(Miacalcic, Sandoz) 100 I.U., 4 times a week for 4 weeks.

Each patient was asked to determine his comfortable walking distance by measuring the distance he was able to walk, at the same time of day, along a certain route at a steady $\omega$ pace. The patients documented their walking $\subseteq$ ability several days before treatment was started, during the second week, and on the last few days of each treatment period.

Clinical assessment was performed by one $\overrightarrow{\bar{B}}$ of the authors (J.S.) before and after each treatment period. Results of treatment and follow-up are summarised in the table which $\frac{\bar{D}}{\bar{D}}$ documents the time that initial and maximal $\frac{\bar{c}}{7}$ response was reached in each patient as well $\varrho$ as maximal walking distance. Since most of the patients needed more than one course of $\omega$ calcitonin injections, the time of repeated $\overrightarrow{0}$ treatment periods is also shown (this is indicated in months after the first treatment $\vec{\omega}$ course).

This unselected group of elderly patients, who suffered from symptoms due to moderately severe LSS, were also suffering $N$ from chronic diseases typical for this age group, such as diabetes mellitus, athero- of sclerotic cardiovascular diseases. However, $\omega$ their poor quality of daily life was deter- 음 mined by their LSS. All patients refused $\rightarrow$ surgical intervention but agreed to paks ticipate in the clinical trial with intramus 응 cular calcitonin.

The response to calcitonin was favourab杘 in five out of six patients. Four patiento showed a rapid initial response. The only non-responding patient suffered from severe LSS with complete myelographic block at $\mathbf{L}_{3-4}$ level. After the "failure" of the medical approach he agreed finally to be operated on and benefited from improvement following surgery.

Surprisingly, four of our patients suffered concomitantly from peripheral neuropathy due to different causes. Their "neuropathic" symptoms and conduction time were not altered by calcitonin.

Table Therapeutic effects of calcitonin in LSS patients

\begin{tabular}{|c|c|c|c|c|c|c|}
\hline \multirow[b]{2}{*}{$\begin{array}{l}\text { Patient } \\
\text { No. }\end{array}$} & \multirow[b]{2}{*}{ Age } & \multicolumn{2}{|c|}{ Walking distance } & \multirow[b]{2}{*}{$\begin{array}{l}\text { Initial } \\
\text { Response } \\
\text { (days) }\end{array}$} & \multirow[b]{2}{*}{$\begin{array}{l}\text { Maximal } \\
\text { Response } \\
\text { (days) }\end{array}$} & \multirow[b]{2}{*}{$\begin{array}{l}\text { Repeated } \\
\text { Courses of } \\
\text { Calcitonin } \\
\text { (months) }\end{array}$} \\
\hline & & $\begin{array}{l}\text { Before } \\
\text { Treatment } \\
\text { (metres) }\end{array}$ & $\begin{array}{l}\text { After } \\
\text { Calcitonin } \\
\text { (metres) }\end{array}$ & & & \\
\hline $\begin{array}{l}1 \\
2 \\
3 \\
4 \\
5 \\
6\end{array}$ & $\begin{array}{l}70 \\
55 \\
64 \\
64 \\
50 \\
74\end{array}$ & $\begin{array}{l}10 \\
500 \\
20-30 \\
100-300 \\
30 \\
50-100\end{array}$ & $\begin{array}{c}3000 \\
1500 \\
500 \\
1500-5000 \\
30 \\
400\end{array}$ & $\begin{array}{l}10 \\
8 \\
28 \\
8 \\
8(\text { temp) } \\
10\end{array}$ & $\begin{array}{r}30 \\
120 \\
90 \\
30 \\
-30\end{array}$ & $\begin{array}{l}11,22 \\
3 \\
3 \\
\frac{-}{3}\end{array}$ \\
\hline
\end{tabular}

*referred for surgery. 
From our limited experience it seems that repeated courses of calcitonin may be needed after a 3-month interval. As many of the LSS patients are elderly and thus present a higher surgical risk, it seems reasonable to try medical treatment first.

\section{JONATHAN STREIFLER} RACHEL HERING NATAN GADOTH Department of Neurology, Beilinson Medical Center,

Petah Tiqva and Tel Aviv University Sackler School of Medicine, Israel.

Address for correspondence: Dr J. Streifler, Department of Neurology, Beilinson Medical Center, Petah Tiqva 49 100, Israel.

\section{References}

1 Hall S, Bartleson JD, Onafrio BM, Baker HL, Okazaki H, O'Duffy JD. Lumbar spinal stenosis: clinical features, diagnostic procedures and results of surgical treatment in 68 patients. Ann Intern Med 1985;103: 271-5.

2 Grabias S. The treatment of spinal stenosis. $J$ Bone Joint Surg 1980;62A:308-13.

3 Porter RW, Hibbert C. Calcitonin treatment for neurogenic claudication. Spine 1983;8: 585-92.

4 Douglas DL, Duckworth T, Kanis JA, Jefferson AA, Martin TJ, Russell RGG. Spinal cord dysfunction in Paget's disease of bone. $J$ Bone Joint Surg 1981;63B:495-503.

5 Deftos LJ, First BP. Calcitonin as a drug. Ann Intern Med 1981;95:192-7.

6 Wooton R, Reeve J, Spellacy E, TellezYudilevich M. Skeletal blood flow in Paget's disease of bone and its response to calcitonin therapy. Clin Sci Mol Med 1978;54:69-74.

Accepted 8 November 1988

\section{Subcutaneous apomorphine in Parkinson's disease}

Sir: Recently, Stibe et al ${ }^{1}$ reported the beneficial effect of subcutaneous apomorphine administration in Parkinsonian on-off oscillations. We have studied in a similar way the effect of apomorphine, a D1 and D2 dopaminergic agonist, administered by continuous infusion in four patients and by multiple injection in six patients. All patients had been suffering from disabling motor fluctuations unresponsive to other treatment strategies. Their mean age was 55.8 years and duration of disease was 9.4 years. Domperidone, a peripheral dopamine antagonist $^{2}, 20 \mathrm{mg}$ three times daily, was given for at least 3 days before adding apomorphine to the other dopaminergic drugs, that is, levodopa + decarboxylase inhibitor (mean dosage $635 \mathrm{mg} /$ day) in all patients, and bromocriptine (mean dosage $31 \mathrm{mg} /$ day) in eight patients.

Subcutaneous apomorphine administration induced a substantial motor benefit in all patients, for up to 6 months. In the four patients treated with an infusion pump, the mean duration of off periods per day was lowered from 6 to $1 \cdot 1$ hours $(82 \%$ improvement), with a mean apomorphine infusion rate of $3.8 \mathrm{mg} / \mathrm{h}$ during diurnal hours plus a mean of four additional boluses of $1.5 \mathrm{mg}$ each. Levodopa dosage fell by $61 \%$. In the six patients treated by a penject, the mean duration of off periods per day was lowered from 4.7 to 1.7 hours $(63 \%$ improvement) with a mean daily number of apomorphine injections of four, the mean dosage of each injection being $2.25 \mathrm{mg}$. Levodopa dosage was reduced by $15 \%$. In two patients, tremor was abolished by apomorphine during on periods, whereas this was not the case with the previous dopaminergic drug intake. Domperidone could be suspended in all patients but one, within 3 weeks after apomorphine initiation. All patients using pumps, and one patient with multiple injections, developed transitory red nodules at the needle sites. In three patients complaining of pruritus at the injection site, peripheral blood eosinophilia occurred. One patient treated by pump complained of visual hallucinations for 2 days, but another patient reported the disappearance of evening and nocturnal hallucinations. No other side effects occurred.

These results confirmed the reports of Stibe $e t a l^{\prime}$ and Poewe $e t a l^{\beta}$ on the sustained improvement of all dopa-dependant symptoms in Parkinsonian patients with motor fluctuations. Moreover, we found that apomorphine could be useful in alleviating severe tremor, resistant to classical drugs. ${ }^{4}$

Since all other dopaminergic drugs could be stopped in one patient, apomorphine does not necessarily require intermittent administration of levodopa to achieve the best effect, as previously suggested. ${ }^{5}$ It is noteworthy that oral high-dosage apomorphine-induced azotaemia $^{6}$ did not develop with subcutaneous, relatively low-dosage administration. As the beneficial motor effect can last many months, central dopaminergic receptors do not seem to become tolerant to chronic apomorphine administration unlike peripheral dopaminergic receptors which are implicated in apomorphine-induced emesis and vegetative effects.

These very encouraging results warrant further long-term studies. Technical improvements in drug-delivery systems an in apomorphine physico-chemical properties are needed to obtain easier utilisation Parkinsonian patients and better subcutan eous tolerance of this new therapeutis method.

Apomorphine hydrochloride was kind supplied by Laboratoire Aguettant, Lyon $\underset{2}{2}$ P POLLAK AS CHAMPA M HOMMEI JE PERRET AL BENAB贯:

Department of Neurolog and INSERM U 318

Centre Hospitalier Régional et Universitairg 38043 Grenoble Cedex.

Franş

References

1 Stibe CMH, Lees AJ, Kempster PA, Stern G Subcutaneous apomorphine in parkinsoniq on-off oscillations. Lancet 1988;i::403-6.

2 Agid Y, Pollak P, Bonnet AM, Signoret JEr Lhermitte F. Bromocriptine associated with a peripheral dopamine blocking agent $\mathcal{B}$ treatment of Parkinson's disease. Lance 1979;i:570-72.

3 Poewe W, Kleedorfer B, Gerstenbrand F, tel W. Subcutaneous apomorphine in Pagic son's disease. Lancet 1988;i:943.

4 Braham I, Sarova-Pinhas I, Goldhamme्̛े $\overrightarrow{\mathrm{V}}$ Apomorphine in parkinsonian tremo둥 Med J 1970;3:768.

5 Obeso JA, Grandas F, Vaamonde J, Luquis MR, Martinez-Lage JM. Apomorphin infusion for motor fluctuations in Parkip son's disease. Lancet 1987;i:1376-7.

6 Cotzias GC, Papavasiliou PS, Tolosa Mendez JS, Bell-Midura M. Treatment Parkinson's disease with aporphines. $N$ En J Med 1976;294:567-72

Accepted 8 November 1988

Lethal neurotoxicity associated to azidothy midine therapy

Sir: Among the toxic side-effects of azido thymidine (AZT), neurological manifestao tions such as headache and mild confusion have frequently been described. There is alsef a case report on lethal neurotoxicity in: association with AZT therapy with focafy seizures and respiratory arrest. ${ }^{\prime}$

We report a similar case of an AIDS patient who died probably of neurotoxicit\& during treatment with AZT. An intravenous drug abuser underwent a first clinică 